The Geological Society of America

Digital Map and Chart Series 17

2014

\title{
Notes on Maps of the Callovian and Tithonian Paleogeography of the Caribbean, Atlantic, and Tethyan Realms: Facies and Environments
}

\author{
Caroline Wilhem* \\ Institute of Earth Sciences, Faculty of Geosciences and Environments, University of Lausanne, \\ Geopolis, 1015 Lausanne, Switzerland
}

\section{A. NOTE}

The Callovian-Tithonian period of the Atlantic and its connected oceans was tectonically intense. It was mainly marked by the opening of the Caribbean Seaway, the pursuance of the Atlantic and Tethyan spreading, as well as the North Atlantic rifting. This period is characterized by a general deepening of the oceans. At the same time, the sedimentation passed from largely siliceous to carbonaceous deposits within the Tethyan realm.

Callovian and Tithonian facies and environments were compiled and added to a plate tectonics model that constrains their arrangements. The elaboration of paleo-environmental maps at large scale hides various regional paleogeographic interpretations and many controversies. With the help of the plate tectonics model, different possibilities emerge and regional interpretations are reconciled at a larger scale. This leads to an alternative paleogeographic model for the Callovian and Tithonian age. These maps show the evolution of sedimentary deposits with their evolving associated tectonic context and may be considered as a useful tool for helping scientists of various disciplines in their research.

The tectonic reconstructions for the Callovian and Tithonian used within the present work are derivative from the 600-0 Ma Neftex Geodynamic Earth Model (@) Neftex Petroleum Consultants Ltd.), which is based on the integration of dynamic plate boundaries, plate buoyancy factor, ocean spreading rates, subduction rates, past synthetic isochrones and global geometric constraints as, well as pluridisciplinary field and laboratory geological data. The methodology of plate tectonic modeling was introduced by Stampfli and Borel (2002) and technically

\footnotetext{
*caroline.wilhem@gmail.com
}

detailed in Hochard (2008). The Mesozoic reconstructions were partly presented and discussed in Flores (2009) for the Pacific and Caribbean realms; in Stampfli and Borel $(2002,2004)$ for the Atlantic realm; and in Stampfli (2000, 2001), Stampfli et al. (2001a, 2001b, 2002, 2003), Stampfli and Borel (2004), Stampfli and Kozur (2006), Bagheri and Stampfli (2008), Bonev and Stampfli (2008, 2011), Moix et al. (2008), and Stampfli and Hochard (2009) for the Tethyan realm.

Key localities and linked references used for the elaboration of the Callovian and Tithonian maps are geographically presented in section B. The Dercourt et al. $(1993,2000)$ atlases were used as general references. The characteristics and development of the various Middle-Late Jurassic facies and environments of the Caribbean, Atlantic, and Tethyan realms are detailed in the latter works.

\section{B. KEY LOCALITIES AND ASSOCIATED REFERENCES}

\section{The Pacific Realm (Pacific Plate)}

$\mathrm{BaCa}-$ Baja California.

Salvador et al. (1992) and Flores (2009).

\section{The Transitional Pacific-Atlantic Realm (Chortis, Yucatan, North, and South American Plates)}

\subsection{Mexico and Gulf of Mexico (United States)}

Chortis: Cho-Chortis; Mix-Mixteca; Oax-Oaxaquia; Tahu-Tahue; Zapo-Zapoteco.

North America: Alda-Adama; Bis-Bisbee; Chi-Chihuahua; Coa-Coahuila Basin; Cor-Cortes; GM-Gulf of Mexico; Hid-Hidalgo; Hui-Huizachal; LPop—La Popa

Wilhem, C., 2014, Notes on Maps of the Callovian and Tithonian Paleogeography of the Caribbean, Atlantic, and Tethyan Realms: Facies and Environments: Geological Society of America Digital Map and Chart Series 17, 9 p., doi:10.1130/2014.DMCH017. For permission to copy, contact editing@ geosociety.org. (C) 2014 The Geological Society of America. All rights reserved. 
C. Wilhem

Basin; Monc-Monclova; Monte-Monterrey; NuRo-Nueva Rosita; PeBl-Penon Blanco; Pic-Picachos; PoRi-Poza Rica; Pue-Puebla; Sabi-Sabinas Basin; Salt-Saltillo; SiMa-Sierra Madre; SLP-San Luis Potosi; Sono-Sonora; TaMi-Tampica-Misant Basina; TanA-Tanaulipas Arch; Vera-Veracruz.

Yucatan: ChiB_Chiapas Basin; ChiM-Chiapas Massif; ChTa_Chiapas Tabasco; MaU—Maya Uplift; SoCa—Sonda de Campeche; Yuc_-Yucatan.

Caballero-Miranda et al. (1990), Salvador et al. (1992), Marton and Buffler (1994), Barboza-Gudino et al. (1999), Franco-Rubio, (1999), Marton and Buffler (1999), AngelesAquino and Cantú-Chapa (2001), Cantú-Chapa (2001), de Antunano (2001), Dickinson and Lawton (2001), Goldhammer and Johnson (2001), Lawton et al. (2001), Meneses-Rocha (2001), Ortega-Gutiérrez et al. (2007), Centeno-García et al. (2008), and Galloway (2008).

\subsection{Caribbean (Cuba, Bahamas)}

Yucatan: Esc-Escambray; Gua-Guaniguanco; PinoPinos.

North America: BaP-Bahamas Plateau; CaGa-Cap Gap; CBP_Cuban Bahamas Platform; Exu_Exuma; Flor-Forida; PuAl-Punta Alegre.

Iturralde-Vinent (1994), Pszczółkowski (1999), and Iturralde-Vinent (2006).

\subsection{Venezuela}

South America: BarB_-Barinos Basin; DemR—Demerara Rise; Espi_Espino; EVB_-East Venezuela Basin; Guaj-Guajira; GuyB - Guyana Basin; LlaB_Llampos Basin; Meri-Merida; Peri-Perijia; Seln-Serrana del Interior; Tri-Trinidad.

Algar and Erikson (1995), Giunta et al. (2002), Ostos et al. (2005), and Pindell and Kennan (2009).

\section{Atlantic Realm (Gondwanian, North American, Iberian, and Eurasian Plates)}

Gondwana: AaTa-Aaiun-Tarfaya Basin; CanI-Canary Islands; CB-Cap Blanc; Essa-Essaouira; GuiT_Guinea Terrace; MazP_Mazagan Plateau; SenBm-Senegal Basin.

North America: BBB-Blake Bahamas Basin; BCTBaltimore Canyon Trough; BP-Blake Plateau; CaHa-Cape Hatteras; CarT-Carolina Trough; GBB_-Grand Bank Basin; GeBB-Georges Bank Basin; JAB_-Jeanne d'Arc Basin; LabS_Labrador Shelf; Rock—Rockall; ScoB_-Scotian Basin.

Iberia: GalB-Galicia Bank; FCB-Flemish Cap Basin; LusB_Lusitanian Basin

Eurasia: PoB-Porcupine Basin; Iri-Irish Basin.

Jansa et al. (1979), Jansa et al. (1982), Ranke et al. (1982), Baumgartner et al. (1983), Ogg et al. (1983), Robertson and Ogg (1986), Gohn (1988), Olsson et al. (1988), Poag and Valentine (1988), Ziegler (1988), Steiner et al. (1998), and Ford and Golonka (2003).

\section{The Tethyan Realm (Gondwanian, Eurasian, Moesian, and Iberian Plates)}

\subsection{Gondwana}

BarrB —-Barreirinhas Basin; ChaB — Chad Basin; FoAmFoz do Amazonas Basin; GhB — Ghadames Basin; LulB_-Lullemeden Basin; MurB-Murzuq Basin; OMB_-Oued Mya Basin; PaMa_Para-Manranhao Basin; SirB —-Sirte Basin; SLL_-Sierra Leone-Liberia Basin; TadB-Taoudeni Basin; TimB-Timimoun Basin; UEgB-Upper Egypt Basin.

Dercourt et al. $(1993,2000)$ and IHS confidential data.

\subsection{Gondwanian Margin}

\subsubsection{Morocco}

Atla-Atlas; ConP-Constantine Platform; ExRi-External Rif; MagP-Maghrebian Platform; MAt-Middle Atlas; Mese-Meseta; TeT-Tellian Trough.

Wildi (1979, 1981, 1983), Hinz et al. (1982), Benzaggagh (2000), Benzaggagh and Habibi (2006), Chalouan et al. (2008), and Frizon de Lamotte et al. (2008).

\subsubsection{Tunisia, Malta, and Sicilia}

Malt_Malta; SPel—Sicilian Pelgian Basin; TPel—Tunisian Pelagian Basin; TuDo_-Tunisian Dorsale; TunT_-Tunisian Trough.

Soussi et al. (2000, 2003), Enay et al. (2005), and Boughdiri et al. (2006, 2007).

4.2.3. Lybia, Arabia, Eastern Turkey, and Iran (Zagros)

Bisi-Bisitoun; CyrP_Cyrenica Platform; KaradKaradut; Kerm—Kermanshah; Hawa_-Hawasina; Haz-Hazro; Hez-Hezan; Mar-Mardin; Hez-Hezan; arB-Marmarica Basin; Mist-Mistah; Ney_Neyriz; Pich-Pichakun.

Bechennec et al. (1990), Fourcade et al. (1991), Barrier and Vrielynck (2007), and Gharib and De Wever (2010).

\subsection{Apulia, Adria, Anatolia, Pelagonia and Pindos, Maliac, Vardar, and Tethyan (Ligurian, Lombardian) Domains \\ 4.3.1. Italy (Sicilia, Apennines, and Southern Alps)}

Adri-Adria; Apu-Apulia; Bel-Belluno; CaLu-Campania-Lucana; Cana-Canavese; Emma_Emma Basin; ExLiExternal Ligurian; Fri_-Friuli; GSR — Gran Sasso Range; InLiInternal Ligurian; LaAb-Latium-Abbruzzi; LaNe-Lago Negro; Lomb_Lombardian; Pano-Panormides; Pol-Pollino; SicB-Sicanian Basin; Tren-Trento Plateau; TusB-Tuscan Basin; UmMa-Umbria Marche; Verb-Verbicaro.

Cousin (1981), Santantonio (1993), Caracuel et al. (1997), Bill et al. (2001), Beccaro et al. (2002), Ferrando et al. (2004), Bazzucchi et al. (2005), Iannace et al. (2005), Marroni and Pandolfi (2007), Chiari et al. (2008), Passeri et al. (2008), Scisciani and Calamita (2009), Channell et al. (2010), Zarcone and Di Stefano (2010), and Santantonio and Carminati (2011).

\subsubsection{Greece (Hellenides)}

Adha-Adhami; Almo-Almopias; Argo-Argolis; AskAskipion; Beo-Beotia; Chio_-Chios; CTri_Creatan Tripolis; DhTr-Dhidhimi-Trapezona; Eth-Ethia; Evia-Evia; Gab- 
Gabrovo; Hyd-Hydra; Io-Ionian; Koz-Koziakas; MaliaMaliac; Mig-Migdhalista; Oth-Othris; Parn-Parnassos; Pax-Paxos; Pin-Pindos; Rho-Rhodes; Saza-Sazani; TaOr-Talea Ori; Theo-Theokafta; Trip-Tripolis; VarVardousia; Vig_-Vigla; Viv_-Vivari.

Aubouin and Dercourt (1962), Bernoulli et al. (1974), Celet et al. (1976), Fleury (1980), Ferrière (1982), Bonneau (1984), Baumgartner (1985), Dercourt et al. (1993), Robertson and Shallo (2000), Robertson and Pickett (2000), Scherreiks (2000), Sharp and Robertson (2006), and Scherreiks et al. (2010).

\subsubsection{Turkey (Anatolides-Taurides)}

Akse-Askeki; Ana-Anamas; Anta-Antalya; BaDaBarla Dag; Bade_Badenli; Bey-Beysehir; Beyda-Beydaglari; Bod-Bodrum; Boya-Boyalitepe; Buc-Bucak; Dat_Datca; Din-Dinar; Gumu—Gumuslu; Hadi-Hadim; Hati-Haticeana; Hug-Huglu; Kara-Karakaya; KebaKeban; Kizi-Kizilca; Koc-Kocali; Koy-Koycegiz; MenMenderes; Pina—Pinarbasi; Seyd—Seydisehir; SuDa—Susuz Dag.

Brunn et al. (1971), Bernoulli et al. (1974), Gutnic et al. (1979), Poisson (1984), Fourcade et al. (1991), Collins and Robertson (1999), Poisson et al. (2003), and Moix et al. (2008).

\subsubsection{Former Yugoslavia (Dinarides)}

Bos-Bosnian; Bud-Budva; Cuka-Cukali; Dal-Dalmatian; Drin-Drinjaca; Dur-Durmitor; Gm—-Gmec; GoKoGorski Kotar; HKa-High Karst; Kolo-Kolovrat; KorabKorabi; Kru-Kruja; Lim_Lim; MaEm-Malesia e Madhe; Mir-Mirdita; Mo-Mostar; PKa-Pre-Karst; RoDe-Romajia-Devetak; Sara-Sarajevo; Soko_-Sokolina; Sos-Sosice; TmGo-Tmovski Gozd; Ulog_Ulog; Val_Valbona; VidVidusa; Viso_-Visocica.

Aubouin (1964), Blanchet (1974), Rampnoux (1974), Chorowicz (1977), Cadet (1978), Charvet (1978), Cousin (1981), Kodra et al. (1993), Goričan (1994), Robertson and Shallo (2000), Tari (2002), Bucković et al. (2004), Bucković (2006a, 2006b), Karamata (2006), Gawlick et al. (2008), and Vishnevskaya et al. (2009).

\subsection{ALCAPA and Meliata Domain (Eastern Alps, Western Carpathians, and Pannonian Basin)}

Baju-Bajuvaric; Bako-Bakony; Biho-Bihor; BuBükk; CaAl_Carnic Alps; Dolo_-Dolomites; Driv-DrinaIvanjica; Fat-Fatric; Geme-Gemeric; Hall-Hallstatt; Hron-Hronic; Jul-Julian; Juva-Juvavic; Kal-Kalnik; LoAA_Lower Austroalpine; Lov_Lovinzola; MAA—Middle Austroalpine; Mec-Mecsek; Med-Medvelica; Mel-Meliata; Sili-Silicic; SKa-South Karawankan; Tat-Tatric; TiroTirolic; Tol-Tolmin; Vahi_Vahic; Vapo_-Vaporic; Zala_Zala; Zum-Zumberak.

Gwinner (1978), Trümpy (1981), Tollmann (1985), Eberli (1988), Froitzheim and Manatschal (1996), Kozur and Mock (1996, 1997), Plašienka et al. (1997), Plašienka (1998), Rakus (1998), Gawlick et al. (1999), Halamić et al. (1999, 2005), Faupl and Wagreich (2000), Haas et al. (2000), Mandl (2000), Gawlick et al. (2002), Csontos and Vörös (2004), Haas and Pero (2004), Froitzheim et al. (2008), Pienkowski et al. (2008), Schmid et al. (2008), Halamić and Klindžić (2009), Gawlick and Schlagintweit (2010), and Missoni and Gawlick (2011).

\subsection{Moesia and Vardar Domain (Romania, Bulgaria, Macedonia, and Northeastern Greece)}

Ani-Anina; Bar-Barlya; Belo-Belogradchik; DanuDanubian; Ele-Elena; ESre-East Srednogorie; GabGabrovo; Get-Getic; Gint-Gintsi; Iz-Izdremets; KotKotel; Mac-Macin; Ni-Nish; Pai-Paikon; Peo-Peonias; Ray-Rayantsi; Rhodo-Rhodope; SApu-South Apuseni; SDob-South Dobrogea; Sev-Severin; SM-Serbo-Macedonian; SuGe-Supra-Getic; Trek-Treklyano; TrSy-Transylvanides; Tul-Tulcea; Yun-Yunak; Zvez-Zvezdets.

Sándulescu (1975), Tchoumatchenko et al. (1992), Tchoumatchenco and Sapunov (1994), Ferrière and Stais (1995), Sapunov (1999), Georgiev et al. (2001), Seghedi (2001), Csontos and Vörös (2004), Lazar et al. (2004), Tchoumatchenco (2006), Lakova et al. (2007), and Sapunov and Metodiev (2007).

\subsection{Eurasia}

Armo-Armorica; Bohe-Bohemian Massif; Cado-Cadomia; EEPM-East European Platform Margin; Karp-Karpinsky; LBM-London Brabant Massif; Rhen-Rhenish Massif; STaM-Stavropol Massif.

Dercourt et al. (1993, 2000) and Daukeev et al. (2002).

\subsection{Eurasian Margin (Carpathians to Provence) 4.7.1. Eastern (Dacides) and Western Carpathians (Pieniny Klippen Belt)}

Buco-Bucovinian; Cea-Ceahlau; Czor-Czorztyn; Magu-Magura; Pien_Pieniny; PoBo_-Poiana Botizii; SileSilesian; $\mathrm{SuBu}$-Subbucovinian.

Sándulescu (1975), Mišík (1994), Krobicki et al. (2003), Aubrecht and Sýkora (2004), Oszczypko et al. (2004), Lewandowski et al. (2005), Sidorczuk (2005), Aubrecht et al. (2006), Oszczypko (2006), Froitzheim et al. (2008), Pienkowski et al. (2008), and Schlögl et al. (2009).

\subsubsection{Western Alps, France, and Corsica}

Ann-Annecy; Bala-Balagne Nappe; Bre-Breche Nappe; Brian-Briançonnais; Cau-Causses; Co-Corsica; Dau-Dauphinois; Dij-Dijon; Fran-Francardo; GenGenève; Gren-Grenoble; He-Helvetic; Jura-Jura; LionGolfe du Lion; Lyon-Lyon; Mars-Marseille; MC-Massif Central; Mont-Montpelier; Nice-Nice; Nies-Niesen Nappe; NHel-North Helvetic; PuCa_-Punta di Calcina; Sept-Plateforme Septentrionale; SubA—Subalpine Basin; SubB-Subbriançonnais; Toul-Toulon; UH-Ultrahelvetic.

Gwinner (1978), Trümpy (1981), Debrand-Passard et al. (1984), Tollmann (1985), Stampfli et al. (1998), Peybernes et al. (2001), Stampfli (2001), Stampfli et al. (2002), Marroni and Pandolfi (2007), Stampfli and Hochard (2009), and Graciansky et al. (2011). 
4.8. Iberia

\subsubsection{Italy (Calabria, Sardinia)}

Cala-Calabria; Calo-Caloveto; MoSo-Monte Soro; Posa-Posada; SuMo-Supramonte; Tac-Tacchi.

Dercourt et al. (1993, 2000), Santantonio (1993), and Costamagna et al. (2007).

4.8.2. Spain (Betic and Balearic Islands) and Morocco (Internal Rif)

Cab-Cabrera; ExSu-External Subbetic; IBet-Internal Betic; IbMe-Iberian Meseta; InRi-Internal Rif; InSuInternal Subbetic; ISu, Intermediate Subbetic; Kaby-Kabylie; Mall-Mallorca; MeSu-Median Subbetic; PBet-Prebetic; $\mathrm{SBe}$-Subbetic.

Wildi (1979), Molina et al. (1999), O’Dogherty et al. (2001), Vera (2001), Aurell et al. (2002), Caracuel et al. (2006), Gómez and Fernández-López (2006), Chalouan et al. (2008), and Aurell et al. (2010).

\section{The Eastern Tethyan Realm (Eurasian, Sakarya, and Iranian Plates)}

\subsection{Turkey (Pontides) and Caucasus}

Baku_Baku; Dzir-Dzirula; EKub_East Kuban; EpoEastern Pontides; GCau—Great Caucasus; Ist_-Istanbul; IzAnIzmir Ankara; Kara—Karakaya; Kark—Karkinitsky; KureKüre; Saka-Sakarya; SCrim-South Crimea; Terek-Terek; TrCa-Transcaucasus; WKub_-West Kuban; Zong-Zonguldak.

Nikishin et al. (1998), Kozur et al. (2000), Nikishin et al. (2001), Daukeev et al. (2002), Barrier and Vrielynck (2007), and Moix et al. (2008).

\subsection{Iran (Sanandaj, Lut-Tabas, and South Caspian)}

Chalu_Chalus; EAlb_Eastern Alborz; Lut_Lut; RashtRasht; Ravar-Ravar; San_-Sanandaj; SCasp_-South Caspian; Sir-Sirjian; Tab_-Tabriz; Tal_-Talesh; Teh-Tehran; YazdYazd.

Stampfli (1978), Berberian and King (1981), Davoudzadeh and Schmidt (1984), Dercourt et al. (1993), Dercourt et al. (2000), Barrier and Vrielynck (2007), and Wilmsen et al. (2009).

\section{ACKNOWLEDGMENTS}

I am grateful to the University of Lausanne for funding this research and I express my gratitude to Professor Peter O. Baumgartner for initiating this project. I am also very grateful to Professor Ron Blakey for his belief that these maps should be published and for his pertinent comments.

I am particularly grateful to the following persons for their rewarding discussions and insight into regional geology: Eric Champod and Jacky Ferrière for the geology of Greece, Patrice Moix for the geology of Turkey, Federico Galster for the geology of the Alps, Gérard Stampfli for general Tethyan geology, and Peter O. Baumgartner for the geology of the Caribbean, Greece, and some other Tethyan regions.
The plate tectonic reconstructions presented here were carried out as part of the research program of the University of Lausanne on the Stampfli geodynamic model, which is now owned by Neftex Petroleum Consultants Ltd. and attached to the "Neftex Geodynamic Earth Model." I am grateful to Neftex for allowing us to present some details from the geodynamic model in this publication.

\section{REFERENCES CITED}

Algar, S., and Erikson, J.P., 1995, Correlation of the Jurassic through Oligocene Stratigraphic Units of Trinidad and northeastern Venezuela: International Geology Review, v. 37, p. 313-334, doi:10.1080/00206819509465406.

Angeles-Aquino, F., and Cantú-Chapa, A., 2001, Subsurface Upper Jurassic stratigraphy in the Campeche Shelf, Gulf of Mexico, in Bartolini, C., Buffler, R.T., and Cantú-Chapa, A., eds., The Western Gulf of Mexico Basin: Tectonics, Sedimentary Basins, and Petroleum Systems: American Association of Petroleum Geologists Memoir, v. 75, p. 343-352.

Aubouin, J., 1964, Esquisse paléogéographique et structurale des chaînes alpines de la Méditerranée moyenne: Geologische Rundschau, v. 53, p. 480-534, doi:10.1007/BF02054549.

Aubouin, J., and Dercourt, J., 1962, Zone préapulienne, zone ionienne et zone du Gavrovo en Péloponnèse occidental: Bulletin de la Société Géologique de France, v. 4, p. 785-793.

Aubrecht, R., and Sýkora, M., 2004, Jurassic-Cretaceous evolution of the Czorsztyn Unit (Pieniny Klippen Belt, Western Carpathians); new aspects: Geolines (Prague), v. 17, p. 15-16.

Aubrecht, R., Krobicki, M., Sýkora, M., Mišík, M., Boorová, D., Schlögl, J., Samajová, E., and Golonka, J., 2006, Early Cretaceous hiatus in the Czorsztyn Succession (Pieniny Klippen Belt, Western Carpathians); submarine erosion or emersion?: Annales Societatis Geologorum Poloniae, v. 76, p. 161-196.

Aurell, M., Meléndez, G., Oloriz, F., Bádenas, B., Caracuel, J.E., García-Ramos, J.C., Goy, A., Linares, A., Quesada, S., Robles, S., Rodriguez-Tovar, F.J., Rosales, I., Sandoval, J., Suarez de Centi, C., Tavera, J.M., and Valenzuela, M.I., 2002, Jurassic, in Gibbons, W., and Moreno, T., eds., The Geology of Spain: Bath, The Geological Society Publishing House, p. 213-253.

Aurell, M., Bádenas, B., Ipas, J., and Ramajo, J., 2010, Sedimentary evolution of an Upper Jurassic epeiric carbonate ramp, Iberian Basin, NE Spain, in van Buchem, F.S.P., Gerdes, K.D., and Esteban, M., eds., Mesozoic and Cenozoic Carbonate Systems of the Mediterranean and the Middle East: Stratigraphic and Diagenetic Reference Models: Geological Society of London Special Publication 329, p. 89-111, doi:10.1144/SP329.5.

Bagheri, S., and Stampfli, G.M., 2008, The Anarak, Jandaq and Posht-e-Badam metamorphic complexes in central Iran; new geological data, relationships and tectonic implications: Tectonophysics, v. 451, p. 123-155, doi:10.1016/j.tecto.2007.11.047.

Barboza-Gudino, J., Tristan-Gonzalez, M., and Torres-Hernandez, J.R., 1999, Tectonic setting of pre-Oxfordian units from central and northeastern Mexico; a review, in Bartolini, C., Wilson, J.L., and Lawton, T.F., eds., Mesozoic Sedimentary and Tectonic History of North-Central Mexico: Geological Society of America Special Paper 340, p. 197-210.

Barrier, E., and Vrielynck, B., eds., 2007, Palaeotectonic Maps of the Middle East: Tectono-Sedimentary-Palinspastic Maps from Late Norian to Pliocene: Commission of the Geological Map of the World, Paris, 14 maps.

Baumgartner, P.O., 1985, Jurassic sedimentary evolution and nappe emplacement in the Argolis Peninsula (Peloponnesus, Greece): Denkschriften der Schweizerischen Naturforschenden Gesellschaft $=$ Mémoires de la Société Helvetiques des Sciences Naturelles, v. 99, 111 p.

Baumgartner, P.O., Sheridan, R.E., Gradstein, F.M., Barnard, L.A., Bliefnick, D.M., Habib, D., Jenden, P.D., Kagami, H., Keenan, E., Kostecki, J., Kvenvolden, K.A., Moullade, M., Ogg, J.G., Robertson, A.H.F., Roth, P.H., Shipley, T.H., Bowdler, J.L., Cotillon, P.H., Halley, R.B., Kinoshita, H., Patton, J.W., Pisciotto, K.A., Premoli-Silva, I., Testarmata, M.M., and Watkins, D.K., 1983, Summary of Middle Jurassic-Early Cretaceous radiolarian biostratigraphy of Site 534 (Blake-Bahama Basin) and correlation to Tethyan sections: Initial Reports of the Deep Sea Drilling Project, v. 76, p. 569-571, doi:10.2973/dsdp.proc.76.122.1983. 
Bazzucchi, P., Bertinelli, A., Ciarapica, G., Marcucci, M., Passeri, L., Rigo, M., Roghi, G., and Anonymous, 2005, The Late Triassic-Jurassic stratigraphic succession of Pignola (Lagonegro-Molise Basin, Southern Apennines, Italy): Bollettino della Società Geologica Italiana, v. 124, p. 143-153.

Beccaro, P., Baumgartner, P.O., and Martire, L., 2002, Radiolarian biostratigraphy of the Fonzaso Formation, Middle-Upper Jurassic, southern Alps, Italy: Micropaleontology, v. 48, p. 43-60.

Bechennec, F., Le Métour, J., Rabu, D., Bourdillon-de-Grissac, C., de Wever, P., Beurrier, M., and Villey, M., 1990, The Hawasina Nappes; stratigraphy, palaeogeography and structural evolution of a fragment of the SouthTethyan passive continental margin, in Robertson, A.H.F., Searle, M.P., and Ries, A.C., eds., The Geology and Tectonics of the Oman Region: Geological Society of London Special Publication 49, p. 213-223, doi:10.1144 /GSL.SP.1992.049.01.14.

Benzaggagh, M., 2000, Le Malm supérieur et le Berriasien dans le Prérif interne et le Mésorif (Rif, Maroc); biostratigraphie, lithostratigraphie, paléogéographie et évolution tectono-sédimentaire: Villeurbanne, U.F.R. des Sciences de la Terre, Documents des Laboratoires de Géologie, v. 152, 319 p.

Benzaggagh, M., and Habibi, M., 2006, Les séries carbonatées du Jurassique supérieur et les niveaux de passage au Crétacé inferieur dans la partie occidentale du Rif externe (Prérif interne et Mésorif, Maroc). Stratigraphie, paléogéographie et évolution tectonosédimentaire: Newsletters on Stratigraphy, v. 42, p. 115-141, doi:10.1127/0078-0421/2006/0042-0115.

Berberian, M., and King, G.C.P., 1981, Towards a paleogeography and tectonic evolution of Iran: Canadian Journal of Earth Sciences, v. 18, p. 210-265, doi:10.1139/e81-019.

Bernoulli, D., De Graciansky, P.C., and Monod, O., 1974, The Extension of the Lycian Nappes (SW Turkey) into the Southeastern Aegean Islands: Eclogae Geologicae Helvetiae, v. 67, p. 39-90.

Bill, M., O’Dogherty, L., Guex, J., Baumgartner, P.O., and Masson, H., 2001, Radiolarite ages in Alpine-Mediterranean ophiolites: Constraints on the oceanic spreading and the Tethys-Atlantic connection: Geological Society of America Bulletin, v. 113, p. 129-143, doi:10.1130/0016-7606(2001) $113<0129$ :RAIAMO $>2.0$. CO 2 .

Blanchet, R., 1974, De l'Adriatique au bassin pannonique: Essai d'un modèle de chaîne alpine: Mémoires de la Société Géologique de France 120, 167 p.

Bonev, N., and Stampfli, G., 2008, Petrology, geochemistry and geodynamic implications of Jurassic island arc magmatism as revealed by mafic volcanic rocks in the Mesozoic low-grade sequence, eastern Rhodope, Bulgaria: Lithos, v. 100, p. 210-233, doi:10.1016/j.lithos.2007.06.019.

Bonev, N., and Stampfli, G., 2011, Alpine tectonic evolution of a Jurassic subduction-accretionary complex: Deformation, kinematics and ${ }^{40} \mathrm{Ar} /{ }^{39} \mathrm{Ar}$ age constraints on the Mesozoic low-grade schists of the Circum-Rhodope Belt in the eastern Rhodope-Thrace region, Bulgaria-Greece: Journal of Geodynamics, v. 52, p. 143-167, doi:10.1016/j.jog.2010.12.006.

Bonneau, M., 1984, Correlation of the Hellenide nappes in the south-east Aegean and their tectonic reconstruction, in Dixon, J.E., and Robertson, A.H.F., eds, The Geological Evolution of the Eastern Mediterranean: Geological Society of London Special Publication 17, p. 517-527.

Boughdiri, M., Sallouhi, H., Maalaoui, K., Soussi, M., and Cordey, F., 2006, Calpionellid zonation of the Jurassic-Cretaceous transition in northAtlasic Tunisia; updated Upper Jurassic stratigraphy of the "Tunisian Trough" and regional correlations: Comptes Rendus Geoscience, v. 338, p. 1250-1259, doi:10.1016/j.crte.2006.09.015.

Boughdiri, M., Cordey, F., Sallouhi, H., Maalaoui, K., Masrouhi, A., and Soussi, M., 2007, Jurassic radiolarian-bearing series of Tunisia; biostratigraphy and significance to western Tethys correlations: Swiss Journal of Geosciences, v. 100, p. 431-441, doi:10.1007/s00015-007-1237-x.

Brunn, J.H., Dumont, J.F., Graciansky, P.C. de, Gutnic, M., Juteau, T., Marcoux, J., Monod, O., and Poisson, A., 1971, Outline of the geology of the western Taurids: Tripoli, Petroleum Exploration Society of Libya, Annual Field Conference Guidebook, v. 13, p. 225-255.

Bucković, D., 2006a, Jurassic limestone units of Sosice, Mt Zumberak, Croatia; sedimentary signatures of the platform and basin transition: Acta Geologica Hungarica, v. 49, p. 355-371, doi:10.1556/AGeol.49.2006.4.4.

Bucković, D., 2006b, Jurassic section of Gorski Kotar (Western Karst Dinarides, Croatia) facies characteristics, depositional setting and paleogeographic implications: Acta Geologica Hungarica, v. 49, p. 331-354, doi:10.1556/AGeol.49.2006.4.3.

Bucković, D., Tesović, B.C., and Gušić, I., 2004, Late Jurassic paleoenvironmental evolution of the western Dinarides; Croatia: Geologica Carpathica, v. 55, p. 3-18.
Caballero-Miranda, C.I., Morán-Zenteno, D.J., Urrutia-Fucugauchi, J., SilvaRomo, G., Böhnel, H., Jurado-Chichay, Z., and Cabral-Cano, E., 1990, Paleogeography of the northern portion of the Mixteca terrain, southern Mexico, during the Middle Jurassic: Journal of South American Earth Sciences, v. 3, p. 195-211, doi:10.1016/0895-9811(90)90003-J.

Cadet, J.P., 1978, Essai sur l'évolution alpine d'une paléomarge continentale; les confins de la Bosnie-Herzegovine et du Monténegro (Yougoslavie): Mémoires de la Société Géologique de France 133, 83 p.

Cantú-Chapa, A., 2001, Mexico as the western margin of Pangea based on biogeographic evidence from the Permian to the Lower Jurassic, in Bartolini, C., Buffler, R.T., and Cantú-Chapa, A., eds., The Western Gulf of Mexico Basin: Tectonics, Sedimentary Basins, and Petroleum Systems: American Association of Petroleum Geologists Memoir, v. 75, p. 1-27.

Caracuel, J.E., Olóriz, F., and Sarti, C., 1997, Environmental evolution during the Late Jurassic at Lavarone (Trento Plateau, Italy): Palaeogeography, Palaeoclimatology, Palaeoecology, v. 135, p. 163-177, doi:10.1016 /S0031-0182(97)00030-8.

Caracuel, J.E., Sandoval, J., Martín-Martín, M., Estévez-Rubio, A., and MartínRojas, I., 2006, Jurassic biostratigraphy and paleoenvironmental evolution of the Malaguide complex from Sierra Espuña (Internal Betic Zone, SE Spain): Geobios, v. 39, p. 25-42, doi:10.1016/j.geobios.2004.09.002.

Celet, P., Clément, B., and Ferrière, J., 1976, La zone béotienne en Grèce; implications paléogéographiques et structurales: Eclogae Geologicae Helvetiae, v. 69, p. 577-599.

Centeno-García, E., Guerrero-Suastegui, M., and Talavera-Mendoza, O., 2008, The Guerrero Composite Terrane of western Mexico: Collision and subsequent rifting in a supra-subduction zone, in Draut, A.E., Clift, P.D., and Scholl, D.W., eds., Formation and Applications of the Sedimentary Record in Arc Collision Zones: Geological Society of America Special Paper 436, p. 279-308, doi:10.1130/2008.2436(13).

Chalouan, A., Michard, A., Kadiri, K., Negro, F., Lamotte, D., Soto, J.I., and Saddiqi, O., 2008, The Rif Belt, in Michard, A., Saddiqi, O., Chalouan, A., and Lamotte, D., eds., Continental Evolution: The Geology of Morocco: Lecture Notes in Earth Sciences, v. 116, p. 203-302.

Channell, J.E.T., Casellato, C.E., Muttoni, G., and Erba, E., 2010, Magnetostratigraphy, nannofossil stratigraphy and apparent polar wander for Adria-Africa in the Jurassic-Cretaceous boundary interval: Palaeogeography, Palaeoclimatology, Palaeoecology, v. 293, p. 51-75, doi:10.1016/j .palaeo.2010.04.030.

Charvet, J., 1978, Essai sur un orogène alpin; géologie des Dinarides au niveau de la transversale de Sarajevo (Yougoslavie): Publication de la Société Géologique du Nord, v. 2, 479 p.

Chiari, M., Di Stefano, P., and Parisi, G., 2008, New stratigraphical data on the Middle-Late Jurassic biosiliceous sediments from the Sicanian basin, Western Sicily (Italy): Swiss Journal of Geosciences, v. 101, p. 415-429, doi:10.1007/s00015-008-1276-y.

Chorowicz, J., 1977, Etude géologique des Dinarides le long de la transversale Split-Karlovac, Yougoslavie: Publication de la Société Géologique du Nord, v. 1, 331 p.

Collins, A.S., and Robertson, A.H.F., 1999, Evolution of the Lycian Allochthon, western Turkey, as a north-facing late Palaeozoic to Mesozoic rift and passive continental margin: Geological Journal, v. 34, p. 107-138, doi:10.1002/(SICI)1099-1034(199901/06)34:1/2<107::AID-GJ817>3.0 .CO;2-L.

Costamagna, L.G., Barca, S., and Lecca, L., 2007, The Bajocian-Kimmeridgian Jurassic sedimentary cycle of eastern Sardinia: Stratigraphic, depositional and sequence interpretation of the new "Baunei Group": Comptes Rendus Geoscience, v. 339, p. 601-612, doi:10.1016/j.crte.2007.07.010.

Cousin, M., 1981, Les rapports Alpes-Dinarides: Publication de la Société Géologique du Nord, v. 5, 521 p.

Csontos, L., and Vörös, A., 2004, Mesozoic plate tectonic reconstruction of the Carpathian region: Palaeogeography, Palaeoclimatology, Palaeoecology, v. 210, p. 1-56, doi:10.1016/j.palaeo.2004.02.033.

Daukeev, S.Z., Uzhkenov, B.S., Miletenko, N.V., Morozov, A.F., Leonov, Y.G., Wang, F., Akhmedov, N.A., Abdullayev, E.K., Murzagaziyev, S.M., Orifov, A.O., and Ali-Zade, A.A., 2002, Atlas of the lithology-paleogeographical, structural, palinspastic and geoenvironmental maps of central Eurasia: Almaty, Scientific Research Institute of Natural Resources YUGGEO, 26 sheets, 37 folded sheets.

Davoudzadeh, M., and Schmidt, K., 1984, A review of the Mesozoic paleogeography and paleotectonic evolution of Iran: Neues Jahrbuch für Geologie und Palaeontologie - Abhandlungen, v. 168, p. 182-207. 
de Antunano, S.E., 2001, Geologic evolution and gas resources of the Sabinas Basin in northeastern Mexico, in Bartolini, C., Buffler, R.T., and CantúChapa, A., eds., The Western Gulf of Mexico Basin: Tectonics, Sedimentary Basins, and Petroleum Systems: American Association of Petroleum Geologists Memoir 75, p. 241-270.

Debrand-Passard, S., Courbouleix, S., and Lienhardt, M.J., 1984, Synthèse géologique du sud-est de la France: Orléans, Mémoires du BRGM 125 and 126, $615 \mathrm{p}$.

Dercourt, J., Ricou, L.E., and Vrielynck, B., 1993, Atlas Tethys of Palaeoenvironmental Maps: Commission for the Geologic Map of the World, Paris, 14 maps and explanatory notes.

Dercourt, J., Gaetani, M., Vrielynck, B., Barrier, E., Biju-Duval, B., Brunet, M.F., Cadet, J.P., Crasquin, S., and Sandulescu, M., eds., 2000, Atlas Peri-Tethys: Commission for the Geologic Map of the World, Paris, 24 maps plus notes.

Dickinson, W.R., and Lawton, T.F., 2001, Carboniferous to Cretaceous assembly and fragmentation of Mexico: Geological Society of America Bulletin, v. 113, p. 1142-1160, doi:10.1130/0016-7606(2001)113<1142:CTCAAF> 2.0.CO;2.

Eberli, G.P., 1988, The evolution of the southern continental margin of the Jurassic Tethys ocean as recorded in the Allgaeu Formation of the Austroalpine Nappes of Graubuenden (Switzerland): Eclogae Geologicae Helvetiae, v. 81, p. $175-214$.

Enay, R., Hantzpergue, P., Soussi, M., and Mangold, C., 2005, La limite Kimméridgien-Tithonien et l'âge des formations du Jurassique supérieur de la Dorsale tunisienne, comparaisons avec l'Algérie et la Sicile: Geobios, v. 38, p. 437-450, doi:10.1016/j.geobios.2004.01.001.

Faupl, P., and Wagreich, M., 2000, Late Jurassic to Eocene palaeogeography and geodynamic evolution of the Eastern Alps: Mitteilungen der Oesterreichischen Geologischen Gesellschaft, v. 92, p. 79-94.

Ferrando, S., Bernoulli, D., and Compagnoni, R., 2004, The Canavese Zone (internal Western Alps); a distal margin of Adria: Schweizerische Mineralogische und Petrographische Mitteilungen, v. 84, p. 237-256.

Ferrière, J., 1982, Paléogeographies et Tectoniques superposées dans les Hellenides Internes: Pulication de la Société Géologique du Nord, v. 8, 970 p.

Ferrière, J., and Stais, A., 1995, Nouvelle interprétation de la suture téthysienne vardarienne d'après l'analyse des séries de Peonias (Vardar oriental, Hellenides internes): Bulletin de la Société Géologique de France, v. 166, p. 327-339.

Fleury, J.-J., 1980, Les zones de Cavrovo-Tripolitza et du Pinde-Olonos (Grèce continentale et Péloponnèse du Nord); évolution d'une plate-forme et d'un bassin dans leur cadre alpin: Publication de la Société Géologique du Nord, v. 4, 648 p.

Flores, K., 2009, Mesozoic Oceanic Terranes of Southern Central AmericaGeology, Geochemistry and Geodynamics [Ph.D. thesis]: Lausanne, Switzerland, Université de Lausanne, $317 \mathrm{p}$.

Ford, D., and Golonka, J., 2003, Phanerozoic paleogeography, paleoenvironment and lithofacies maps of the circum-Atlantic margins: Marine and Petroleum Geology, v. 20, p. 249-285, doi:10.1016/S0264-8172(03)00041-2.

Fourcade, E., Dercourt, J., Gunay, Y., Azema, J., Kozlu, H., Bellier, J.P., Cordey, F., Cros, P., De Wever, P., Enay, R., Hernandez, J., Lauer, J.P., and Vrielynck, B., 1991, Stratigraphie et paleogeographie de la marge septentrionale de la plate-forme arabe au mesozoique (Turquie du sud-est): Bulletin de la Société Géologique de France, v. 5, p. 27-41.

Franco-Rubio, M., 1999, Geology of the basement below the decollement surface, Sierra de Catorce, San Luis Potosi, Mexico, in Bartolini, C., Wilson, J.L., and Lawton, T.F., eds., Mesozoic Sedimentary and Tectonic History of North-Central Mexico: Geological Society of America Special Paper 340, p. 211-227.

Frizon de Lamotte, D., Zizi, M., Missenard, Y., Hafid, M., Azzouzi, M., Maury, R.C., Charrière, A., Taki, Z., Benammi, M., and Michard, A., 2008, The Atlas System, in Michard, A., Saddiqi, O., Chalouan, A., and Lamotte, D., eds., Continental Evolution: The Geology of Morocco: Berlin, Springer Lecture Notes in Earth Sciences, v. 116, p. 133-202.

Froitzheim, N., and Manatschal, G., 1996, Kinematics of Jurassic rifting, mantle exhumation, and passive-margin formation in the Austroalpine and Penninic nappes (eastern Switzerland): Geological Society of America Bulletin, v. 108, p. 1120-1133, doi:10.1130/0016-7606(1996)108<1120:KOJRME> 2.3.CO;2.

Froitzheim, N., Plasienka, D., and Schuster, R., 2008, Alpine tectonics of the Alps and Western Carpathians, in McMann, T., ed., The Geology of Central Europe; Volume 2, Mesozoic and Cenozoic: London, Geological Society of London, p. 1141-1232.
Galloway, W.E., 2008, Depositional evolution of the Gulf of Mexico sedimentary basin, in Miall, A.D., ed., The Sedimentary Basins of the United States and Canada: Amsterdam, Elsevier, p. 505-549.

Gawlick, H.-J., and Schlagintweit, F., 2010, The drowning sequence of Mount Bürgl in the Salzkammergut area (Northern Calcareaous Alps, Austria): Evidence for a diachronous Late Jurassic to Early Cretaceaous drowning of the Plassen carbonate platform: Austrian Journal of Earth Sciences, v. 103 , p. $58-75$.

Gawlick, H.-J., Frisch, W., Vecsei, A., Steiger, T., and Böhm, F., 1999, The change from rifting to thrusting in the Northern Calcareous Alps as recorded in Jurassic sediments: Geologische Rundschau, v. 87, p. 644-657, doi:10.1007/s005310050237.

Gawlick, H.-J., Frisch, W., Missoni, S., and Suzuki, H., 2002, Middle to Late Jurassic radiolarite basins in the central part of the Northern Calcareous Alps as a key for the reconstruction of their early tectonic history; an overview: Memorie della Società Geologica Italiana, v. 57, p. 123-132.

Gawlick, H.-J., Frisch, W., Hoxha, L., Dumitrica, P., Krystyn, L., Lein, R., Missoni, S., and Schlagintweit, F., 2008, Mirdita Zone ophiolites and associated sediments in Albania reveal Neotethys Ocean origin: International Journal of Earth Sciences, v. 97, p. 865-881, doi:10.1007/s00531-007-0193-z.

Georgiev, G., Dabovski, C., and Stanisheva-Vassileva, G., 2001, East Srednogorie-Balkan Rift Zone, in Ziegler, P.A., Cavazza, W., Robertson, A.H.F., and Crasquin-Soleau, S., eds., Stratigraphy and Evolution of Peri-Tethyan Platforms: Paris, Mémoires du Muséum National d'Histoire Naturelle, Peri-Tethys Memoir 6, v. 186, p. 259-293.

Gharib, F., and De Wever, P., 2010, Radiolaires mésozoïques de la formation de Kermanshah (Iran): Comptes Rendus Palévol 9, p. 209-219, doi:10.1016/j.crpv.2010.06.003.

Giunta, G., Beccaluva, L., Coltorti, M., Siena, F., and Vaccaro, C., 2002, The southern margin of the Caribbean Plate in Venezuela; tectono-magmatic setting of the ophiolitic units and kinematic evolution: Lithos, v. 63, p. 19-40, doi:10.1016/S0024-4937(02)00120-2.

Gohn, G.S., 1988, Late Mesozoic and early Cenozoic geology of the Atlantic Coastal Plain; North Carolina to Florida, in Sheridan, R.E., and Grow, J.A., eds., The Atlantic Continental Margin, U.S.: Boulder, Colorado, Geological Society of America, Geology of North America, v. 1-2, p. $107-130$.

Goldhammer, R.K., and Johnson, C.A., 2001, Middle Jurassic-Upper Cretaceous paleogeographic evolution and sequence-stratigraphic framework of the Northwest Gulf of Mexico rim, in Bartolini, C., Buffler, R.T., and Cantú-Chapa, A., eds., The Western Gulf of Mexico Basin: Tectonics, Sedimentary Basins, and Petroleum Systems: American Association of Petroleum Geologists Memoir, v. 75, p. 45-81.

Gómez, J.J., and Fernández-López, S.R., 2006, The Iberian Middle Jurassic carbonate-platform system: Synthesis of the palaeogeographic elements of its eastern margin (Spain): Palaeogeography, Palaeoclimatology, Palaeoecology, v. 236, p. 190-205, doi:10.1016/j.palaeo.2005.11.008.

Goričan, S., 1994, Jurassic and Cretaceous radiolarian biostratigraphy and sedimentary evolution of the Budva Zone (Dinarides, Montenegro): Lausanne, Mémoires de Geologie, v. 18, 176 p.

Graciansky, P.-C.D., Roberts, D.G., and Tricart, P., eds., 2011, The Western Alps, from Rift to Passive Margin to Orogenic Belt: Amsterdam, Elsevier, $432 \mathrm{p}$.

Gutnic, M., Monod, O., Poisson, A., and Dumont, J.-F., 1979, Géologie des Taurides occidentales (Turquie): Mémoires de la Société Géologique de France, v. 137, $112 \mathrm{p}$

Gwinner, M.P., 1978, Geologie der Alpen; Stratigraphie, Palaeogeographie, Tektonik: Stuttgart, E. Schweizerbart'sche Verlagsbuchhandlung, 477 p.

Haas, J., and Pero, C., 2004, Mesozoic evolution of the Tisza Mega-unit: International Journal of Earth Sciences, v. 93, p. 297-313, doi:10.1007 /s00531-004-0384-9.

Haas, J., Mioč, P., Pamić, J., Tomljenović, B., Árkai, P., Bérczi-Makk, A., Koroknai, B., Kovács, S., and Rálisch-Felgenhauer, E., 2000, Complex structural pattern of the Alpine-Dinaridic-Pannonian triple junction: International Journal of Earth Sciences, v. 89, p. 377-389, doi:10.1007 /s005310000093.

Halamić, J., and Klindžić, R.S., 2009, Radiolarites and radiolarian cherts in northern Croatia-Possible sources for the production of artifacts: Archeometriai Mühely, v. 3, p. 19-24.

Halamić, J., Goričan, S., Slovenec, D., and Kolar-Jurkovšek, T., 1999, A Middle Jurassic radiolarite-clastic succession from the Medvednica Mt. (NW Croatia): Geologia Croatica, v. 52, p. 29-57. 
Halamić, J., Marchig, V., and Goričan, S., 2005, Jurassic radiolarian cherts in north-western Croatia; geochemistry, material provenance and depositional environment: Geologica Carpathica (Bratislava), v. 56, p. 123-136.

Hinz, K., Dostmann, H., Fritsch, J., von Rad, U., Sarnthein, M., and Seibold, E., 1982, The continental margin of Morocco; seismic sequences, structural elements and geological development, in von Rad, U., Hinz, K., Sarnthein, M., and Seibold, E., eds., Geology of the Northwest African Continental Margin: Berlin, Springer-Verlag, p. 34-60.

Hochard, C., 2008, GIS and Geodatabases Application to Global Scale Plate Tectonics Modelling [Ph.D. thesis]: Lausanne, Switzerland, University of Lausanne, $164 \mathrm{p}$.

Iannace, A., Bonardi, G., D’Errico, M., Mazzoli, S., Perrone, V., and Vitale, S. 2005, Structural setting and tectonic evolution of the Apennine Units of northern Calabria: Comptes Rendus Geoscience, v. 337, p. 1541-1550, doi:10.1016/j.crte.2005.09.003.

Iturralde-Vinent, M.A., 1994, Cuban geology: A new plate tectonic synthesis: Journal of Petroleum Geology, v. 17, p. 39-69, doi:10.1111/j.1747-5457 .1994.tb00113.x.

Iturralde-Vinent, M.A., 2006, Meso-Cenozoic Caribbean paleogeography: Implications for the historical biogeography of the region: International Geology Review, v. 48, p. 791-827, doi:10.2747/0020-6814.48.9.791.

Jansa, L.F., Enos, P., Tucholke, B.E., Gradstein, F.M., and Sheridan, R.E., 1979, Mesozoic-Cenozoic sedimentary formations of the North American Basin; western North Atlantic: Washington, D.C., American Geophysical Union, Maurice Ewing Series, v. 3, p. 1-57, doi:10.1029/ME003p0001.

Jansa, L.F., Wiedmann, J., von Rad, U., Hinz, K., Sarnthein, M., and Seibold, E., 1982, Mesozoic-Cenozoic development of the eastern North American and Northwest African continental margins; a comparison, in von Rad, U., Hinz, K., Sarnthein, M., and Seibold, E., eds., Geology of the Northwest African Continental Margin: Berlin, Springer-Verlag, p. 215-269.

Karamata, S., 2006, The geological development of the Balkan Peninsula related to the approach, collision and compression of Gondwanan and Eurasian units, in Robertson, A.H.F., and Mountrakis, D.A., eds., Tectonic Development of the Eastern Mediterranean Region: Geological Society of London Special Publication 260, p. 155-178, doi:10.1144 /GSL.SP.2006.260.01.07.

Kodra, A., Gjata, K., and Bakalli, F., 1993, Les principales étapes de l'évolution paléogéographique et géodynamique des Albanides internes au cours du Mésozoïque: Bulletin de la Société Géologique de France, v. 164, p. 69-77.

Kozur, H., and Mock, R., 1996, New paleogeographic and tectonic interpretations in the Slovakian Carpathians and their implications for correlations with the Eastern Alps. Part 1: Central Western Carpathians: Mineralia Slovaca, v. 28, p. 151-174.

Kozur, H., and Mock, R., 1997, New palaegeographic and tectonic interpretations in the Slovakian Carpathians and their implications for correlations with the Eastern Alps and other parts of the Western Tethys. Part II: Inner Western Carpathians: Mineralia Slovaca, v. 29, p. 164-209.

Kozur, H.W., Aydin, M., Demir, O., Yakar, H., Göncüoglu, M.C., and Kuru, F., 2000, New stratigraphic and palaeogeographic results from the Palaeozoic and early Mesozoic of the Middle Pontides (northern Turkey) in the Azdavay, Devrekani, Kure and Inebolu areas; implications for the Carboniferous-Early Cretaceous geodynamic evolution and some related remarks to the Karakaya Oceanic Rift Basin: Geologia Croatica, v. 53, p. 209-268.

Krobicki, M., Golonka, J., and Aubrecht, R., 2003: Pieniny Klippen Belt: General geology and geodynamic evolution, in Golonka, J., and Lewandowski, M., eds., Geology, Geophysics, Geothermics and Deep Structure of the West Carpathians and Their Basement: Warsawa Publications of the Institute of Geophysics, Polish Academy of Sciences, v. 28, p. 25-33.

Lakova, I., Tchoumatchenco, P., Ivanova, D., and Koleva-Rekalova, E., 2007, Callovian to Lower Cretaceous pelagic carnoates in the West Balkan Mountains (Komshtitsa and Barlya sections): Integrated biostratigraphy and microfacies: Geologica Balcanica, v. 36, p. 81-89.

Lawton, T.F., Giles, K.A., Vega, F.J., and Rosales-Dominguez, C., 2001, Stratigraphy and origin of the La Popa Basin, Nuevo Leon and Coahuila, Mexico, in Bartolini, C., Buffler, R.T., and Cantú-Chapa, A., eds., The Western Gulf of Mexico Basin: Tectonics, Sedimentary Basins, and Petroleum Systems: American Association of Petroleum Geologists Memoir 75 , p. $219-240$.

Lazar, I., Barbu, V., and Popa, M.E., 2004, Contributions to the Middle Jurassic of the Anina area; the bivalve fauna (Part 1): Acta Palaeontologica Romaniae, v. 4, p. 233-246.
Lewandowski, M., Krobicki, M., Matyja, B.A., and Wierzbowski, A., 2005, Palaeogeographic evolution of the Pieniny Klippen Basin using stratigraphic and palaeomagnetic data from the Veliky Kamenets section (Carpathians, Ukraine): Palaeogeography, Palaeoclimatology, Palaeoecology, v. 216, p. 53-72, doi:10.1016/j.palaeo.2004.10.002.

Mandl, G.W., 2000, The Alpine sector of the Tethyan Shelf; examples of Triassic to Jurassic sedimentation and deformation from the Northern Calcareous Alps: Mitteilungen der Oesterreichischen Geologischen Gesellschaft, v. 92 , p. 61-77.

Marroni, M., and Pandolfi, L., 2007, The architecture of an incipient oceanic basin; a tentative reconstruction of the Jurassic Liguria-Piemonte Basin along the Northern Apennines-Alpine Corsica transect: International Journal of Earth Sciences, v. 96, p. 1059-1078, doi:10.1007/s00531-006 $-0163-x$.

Marton, G., and Buffler, R.T., 1994, Jurassic reconstruction of the Gulf of Mexico Basin: International Geology Review, v. 36, p. 545-586, doi:10.1080 /00206819409465475.

Marton, G.L., and Buffler, R.T., 1999, Jurassic-Early Cretaceous tectono-paleogeographic evolution of the southeastern Gulf of Mexico Basin, in Mann, P., ed., Carribean Basins: Amsterdam, Elsevier, p. 63-91.

Meneses-Rocha, J.J., 2001, Tectonic evolution of the Ixtapa Graben, an example of a strike-slip basin of southeastern Mexico; implications for regional petroleum systems, in Bartolini, C., Buffler, R.T., and Cantú-Chapa, A., eds., The Western Gulf of Mexico Basin: Tectonics, Sedimentary Basins, and Petroleum Systems: American Association of Petroleum Geologists Memoir, v. 75, p. 183-216.

Mišík, M., 1994, The Czorsztyn submarine ridge (Jurassic-Lower Cretaceous, Pieniny Klippen Belt); an example of a pelagic swell: Mitteilungen der Oesterreichischen Geologischen Gesellschaft, v. 86, p. 133-140.

Missoni, S., and Gawlick, H.-J., 2011, Jurassic mountain building and Mesozoic-Cenozoic geodynamic evolution of the Northern Calcareous Alps as proven in the Berchtesgaden Alps (Germany): Facies, v. 57, p. 137-186, doi:10.1007/s10347-010-0225-1.

Moix, P., Beccaletto, L., Kozur, H.W., Hochard, C., Rosselet, F., and Stampfli, G.M., 2008, A new classification of the Turkish terranes and sutures and its implication for the paleotectonic history of the region: Tectonophysics, v. 451, p. 7-39, doi:10.1016/j.tecto.2007.11.044.

Molina, J.M., O’Dogherty, L., Sandoval, J., and Vera, J.A., 1999, Jurassic radiolarites in a Tethyan continental margin (Subbetic, southern Spain): Palaeobathymetric and biostratigraphic considerations: Palaeogeography, Palaeoclimatology, Palaeoecology, v. 150, p. 309-330, doi:10.1016 /S0031-0182(98)00219-3.

Nikishin, A.M., Cloetingh, S., Brunet, M.-F., Stephenson, R.A., Bolotov, S.N., and Ershov, A.V., 1998, Scythian Platform, Caucasus and Black Sea region; Mesozoic-Cenozoic tectonic history and dynamics, in CrasquinSoleau, S., and Barrier, E., eds., Stratigraphy and Evolution of PeriTethyan Platforms: Mémoires du Museum National d'Histoire Naturelle, Peri-Tethys Memoir 3, v. 177, p. 163-176.

Nikishin, A.M., Ziegler, P.A., Panov, D.I., Nazarevich, B.P., Brunet, M.-F., Stephenson, R.A., Bolotov, S.N., Korotaev, M.V., and Tikhomirov, P.L., 2001, Mesozoic and Cainozoic evolution of the Scythian Platform-Black Sea-Caucasus domain, in Ziegler, P.A., Cavazza, W., Robertson, A.H.F., and Crasquin-Soleau, S., eds., Stratigraphy and Evolution of Peri-Tethyan Platforms: Mémoires du Muséum National d'Histoire Naturelle, PeriTethys Memoir 6, v. 186, p. 295-346.

O’Dogherty, L., Martín-Algarra, A., Gursky, H.-J., and Aguado, R., 2001, The Middle Jurassic radiolarites and pelagic limestones of the Nieves unit (Rondaide Complex, Betic Cordillera): Basin starvation in a rifted marginal slope of the western Tethys: International Journal of Earth Sciences, v. 90, p. 831-846, doi:10.1007/s005310000124.

Ogg, J.G., Robertson, A.H.F., Jansa, L.F., Sheridan, R.E., Gradstein, F.M., Barnard, L.A., Bliefnick, D.M., Habib, D., Jenden, P.D., Kagami, H., Keenan, E., Kostecki, J., Kvenvolden, K.A., Moullade, M., Roth, P.H., Shipley, T.H., Bowdler, J.L., Cotillon, P.H., Halley, R.B., Kinoshita, H., Patton, J.W., Pisciotto, K.A., Premoli-Silva, I., Testarmata, M.M., and Watkins, D.K., 1983, Jurassic sedimentation history of Site 534 (western North Atlantic) and of the Atlantic-Tethys Seaway: Initial Reports of the Deep Sea Drilling Project, v. 76, p. 829-884, doi:10.2973/dsdp proc.76.141.1983.

Olsson, R.K., Gibson, T.G., Hansen, H.J., and Owens, J.P., 1988, Geology of the northern Atlantic Coastal Plain; Long Island to Virginia, in Sheridan, R.E., and Grow, J.A., eds., The Atlantic Continental Margin, U.S.: Boul- 
der, Colorado, Geological Society of America, Geology of North America, v. $1-2$, p. $87-105$.

Ortega-Gutiérrez, F., Solari, L.A., Ortega-Obregón, C., Elías-Herrera, M., Martens, U., Morán-Icál, S., Chiquín, M., Keppie, J.D., De León, R.T., and Schaaf, P., 2007, The Maya-Chortís boundary: A tectonostratigraphic approach: International Geology Review, v. 49, p. 996-1024, doi:10.2747/0020-6814.49.11.996.

Ostos, M., Yoris, F., and Avé Lallemant, H.G., 2005, Overview of the southeast Caribbean-South American plate boundary zone, in Avé Lallemant, H.G., and Sisson, V.B., eds., Caribbean-South American Plate Interactions, Venezuela: Geological Society of America Special Paper 394, p. 53-89.

Oszczypko, N., 2006, Late Jurassic-Miocene evolution of the Outer Carpathian fold-and-thrust belt and its foredeep basin (Western Carpathians, Poland): Geological Quarterly, v. 50, p. 169-194.

Oszczypko, N., Malata, E., Svábenická, L., Golonka, J., and Marko, F., 2004, Jurassic-Cretaceous controversies in the Western Carpathian Flysch: The "black flysch" case study: Cretaceous Research, v. 25, p. 89-113, doi:10.1016/j.cretres.2003.10.006

Passeri, L., Ciarapica, G., Leonardis, F., Reggiani, L., and Venturi, F., 2008, The Jurassic succession in the western part of the Gran Sasso Range (Central Apennines, Abruzzo, Italy): Bollettino della Società Geologica Italiana, v. 127 , p. $141-149$.

Peybernes, B., Durand-Delga, M., and Cugny, P., 2001, Reconstitution, en Corse, au Jurassique moyen-supérieur, de la marge européenne de l'océan Liguro-Piémontais, grâce à des niveaux repères à Praekurnubia crusei (foraminifère): Comptes Rendus de l'Académie des Sciences, Série II: Sciences de la Terre et des Planètes, v. 332, p. 499-506.

Pienkowski, G., Schudack, M.E., Bosak, P., Enay, R., Feldman-Olszewska, A., Golonka, J., Gutowski, J., Herngreen, G.F.W., Jordan, P., Krobicki, M., Lathuiliere, B., Leinfelder, R.R., Michalik, J., Moennig, E., NoeNygaard, N., Palfy, J., Pint, A., Rasser, M.W., Reisdorf, A.G., Schmid, D.U., Schweigert, G., Surlyk, F., Wetzel, A., and Wong, T.E., 2008, Jurassic, in McCann, T., ed., The Geology of Central Europe, Mesozoic and Cenozoic: London, Geological Society of London, v. 2, p. 823-922.

Pindell, J.L., and Kennan, L., 2009, Tectonic evolution of the Gulf of Mexico, Caribbean and northern South America in the mantle reference frame; an update, in James, K.H., Lorente, M.A., and Pindell, J.L., eds., The Origin and Evolution of the Caribbean Plate: Geological Society of London Special Publication 328, 1-55.

Plašienka, D., 1998, Geodynamic Development of the Central Western Carpathians during the Jurassic and Cretaceous: Paleotectonic Evolution of the Central Western Carpathians during the Jurassic and Cretaceaous: Geological Survey of Slovak Republic, Bratislava, 290 p.

Plašienka, D., Grecula, M., Putis, M., Kováč, M., and Hovorka, D., 1997, Evolution and structure of the Western Carpathians: An overview, in Grecula, P., Hovorka, D., and Putis, M., eds., Geological Evolution of the Western Carpathians: Mineralia Slovaca, Bratislava, p. 1-24.

Poag, C.W., and Valentine, P.C., 1988, Mesozoic and Cenozoic stratigraphy of the United States Atlantic continental shelf and slope, in Sheridan, R.E., and Grow, J.A., eds., The Atlantic Continental Margin, U.S.: Boulder, Colorado, Geological Society of America, Geology of North America, v. $1-2$, p. $67-85$.

Poisson, A., 1984, The extension of the Ionian trough into southwestern Turkey, in Dixon, J.E., and Robertson, A.H.F., eds., The Geological Evolution of the Eastern Mediterranean: Geological Society of London Special Publication 17, p. 241-249, doi:10.1144/GSL.SP.1984.017.01.18.

Poisson, A., Yağmurlu, F., Bozcu, M., and Sentürk, M., 2003, New insights on the tectonic setting and evolution around the apex of the Isparta Angle (SW Turkey): Geological Journal, v. 38, p. 257-282, doi:10.1002/gj.955.

Pszczółkowski, A., 1999, The exposed passive margin of North America in western Cuba, in Mann, P., ed., Carribean Basins: Sedimentary Basins of the World: Amsterdam, Elsevier, v. 4, p. 93-121.

Rakus, M., 1998, Basic paleogeographic and paleotectonic units of the Western Carpathians, in Rakus, M., ed., Geodynamic Development of the Western Carpathians: Bratislava, Geological Survey of Slovak Republic, p. 15-26.

Rampnoux, J.-P., 1974, Contribution à l'étude géologique des Dinarides; un secteur de la Serbie méridionale et du Monténégro oriental (Yougoslavie): Mémoires de la Société Géologique de France, v. 52, 100 p.

Ranke, U., von Rad, U., Wissmann, G., Hinz, K., Sarnthein, M., and Seibold, E., 1982, Stratigraphy, facies and tectonic development of the on- and offshore Aaiun-Tarfaya Basin; a review, in von Rad, U., ed., Geology of the Northwest African Continental Margin: Berlin, Springer-Verlag, p. 86-105.
Robertson, A.H.F., and Ogg, J.G., 1986, Palaeoceanographic setting of the Callovian North Atlantic, in Summerhayes, C.P., and Shackleton, N.J., eds., North Atlantic Palaeoceanography: Geological Society of London Special Publication 21, p. 283-298, doi:10.1144/GSL.SP.1986.021.01.21.

Robertson, A.H.F., and Pickett, E.A., 2000, Palaeozoic-early Tertiary Tethyan evolution of melanges, rift and passive margin units in the Karaburun Peninsula (western Turkey) and Chios Island (Greece), in Bozkurt, E., and Winchester, J.A., eds., Tectonics and Magmatism in Turkey and the Surrounding Area: Geological Society of London Special Publication 173, p. $43-82$.

Robertson, A., and Shallo, M., 2000, Mesozoic-Tertiary tectonic evolution of Albania in its regional eastern Mediterranean context: Tectonophysics, v. 316, p. 197-254, doi:10.1016/S0040-1951(99)00262-0.

Salvador, A., Westermann, G.E.G., Oloriz, F., Gordon, M.B., and Gursky, H.J., 1992, Meso-America, in Westermann, G.E.G., ed., The Jurassic of the Circum-Pacific: Cambridge, UK, Cambridge University Press, p. 93-121.

Sándulescu, M., 1975, Essai de synthèse structurale des Carpathes: Bulletin de la Société Géologique de France, v. 17, p. 299-358.

Santantonio, M., 1993, Facies associations and evolution of pelagic carbonate platform/basin systems: Examples from the Italian Jurassic: Sedimentology, v. 40, p. 1039-1067, doi:10.1111/j.1365-3091.1993.tb01379.x.

Santantonio, M., and Carminati, E., 2011, Jurassic rifting evolution of the Apennines and Southern Alps (Italy): Parallels and differences: Geological Society of America Bulletin, v. 123, p. 468-484, doi:10.1130/B30104.1.

Sapunov, I.G., 1999, The Jurassic in the south-eastern part of Bulgaria (stratigraphy, geodynamics, facies and palaeogeographic evolution): Geologica Balcanica, v. 29, p. $19-59$

Sapunov, I.G., and Metodiev, L.S., 2007, Main features of the Jurassic in Bulgaria: Dokladi na B'lgarskata Akademia na Naukite, v. 60, p. 169-178.

Scherreiks, R., 2000, Platform margin and oceanic sedimentation in a divergent and convergent plate setting (Jurassic, Pelagonian Zone, NE Evvoia, Greece): International Journal of Earth Sciences, v. 89, p. 90-107, doi:10.1007/s005310050319.

Scherreiks, R., Bosence, D., BouDagher-Fadel, M., Melendez, G., and Baumgartner, P.O., 2010, Evolution of the Pelagonian carbonate platform complex and the adjacent oceanic realm in response to plate tectonic forcing (Late Triassic and Jurassic), Evvoia, Greece: International Journal of Earth Sciences, v. 99, p. 1317-1334, doi:10.1007/s00531-009-0461-1.

Schlögl, J., Mangold, C., Tomašových, A., and Golej, M., 2009, Early and Middle Callovian ammonites from the Pieniny Klippen Belt (Western Carpathians) in hiatal successions: Unique biostratigraphic evidence from sediment-filled fissure deposits: Neues Jahrbuch für Geologie und Palaontologie - Abhandlungen, v. 252, p. 55-79, doi:10.1127/0077-7749 /2009/0252-0055.

Schmid, S., Bernoulli, D., Fügenschuh, B., Matenco, L., Schefer, S., Schuster, R., Tischler, M., and Ustaszewski, K., 2008, The Alpine-Carpathian-Dinaridic orogenic system: Correlation and evolution of tectonic units: Swiss Journal of Geosciences, v. 101, p. 139-183, doi:10.1007/s00015-008-1247-3.

Scisciani, V., and Calamita, F., 2009, Active intraplate deformation within Adria: Examples from the Adriatic region: Tectonophysics, v. 476, p. 57-72, doi: 10.1016/j.tecto.2008.10.030.

Seghedi, A., 2001, The North Dobrogea orogenic belt (Romania); a review, in Ziegler, P.A., Cavazza, W., Robertson, A.H.F., and Crasquin-Soleau, S., eds., Stratigraphy and Evolution of Peri-Tethyan Platforms: Mémoires du Muséum National d'Histoire Naturelle, Peri-Tethys Memoir 6, v. 186, p. 237-257.

Sharp, I.R., and Robertson, A.H.F., 2006, Tectonic-sedimentary evolution of the western margin of the Mesozoic Vardar Ocean; evidence from the Pelagonian and Almopias zones, northern Greece, in Robertson, A.H.F., and Mountrakis, D., eds., Tectonic Development of the Eastern Mediterranean Region: Geological Society of London Special Publication 260, p. 373-412, doi:10.1144/GSL.SP.2006.260.01.16.

Sidorczuk, M., 2005, Middle Jurassic Ammonitico Rosso deposits in the northwestern part of the Pieniny Klippen Belt in Poland and their palaeogeographic importance; a case study from Stankowa Skala and "Wapiennik" Quarry in Szaflary: Annales Societatis Geologorum Poloniae, v. 75, p. $273-285$.

Soussi, M., 2003, Nouvelle nomenclature lithostratigraphique "evenementielle" pour le Jurassique de la Tunisie atlasique: Geobios, v. 36, p. 761-773, doi:10.1016/j.geobios.2003.03.001.

Soussi, M., Mangold, C., Enay, R., Boughdiri, M., and Ben Ismail, M.H., 2000, Le jurassique inférieur et moyen de la Tunisie septentrionale; corrélations 
avec l'axe Nord-Sud et paléogéographie: Geobios, v. 33, p. 437-446, doi:10.1016/S0016-6995(00)80077-7.

Stampfli, G.M., 1978, Etude géologique générale de l'Elburz oriental au S de Gonbad-e-Qabus Iran N-E [Ph.D. thesis]: Geneva, University of Geneva, Switzerland.

Stampfli, G.M., 2000, Tethyan oceans, in Bozkurt, E., and Winchester, J.A., eds., Tectonics and Magmatism in Turkey and the Surrounding Area: Geological Society of London Special Publication 173, p. 1-23.

Stampfli, G.M., ed., 2001, Geology of the Western Swiss Alps: A Guide-Book: Lausanne, Institut de géologie et paléontologie, Université de Lausanne, 195 p.

Stampfli, G.M., and Borel, G.D., 2002, A plate tectonic model for the Paleozoic and Mesozoic constrained by dynamic plate boundaries and restored synthetic oceanic isochrons: Earth and Planetary Science Letters, v. 196, p. 17-33, doi:10.1016/S0012-821X(01)00588-X.

Stampfli, G.M., and Borel, G.D., 2004, The TRANSMED transects in space and time; constraints on the paleotectonic evolution of the Mediterranean domain, in Cavazza, W., Roure, F.M., Spakman, W., Stampfli, G.M., and Ziegler, P.A., eds., The TRANSMED Atlas: The Mediterranean Region from Crust to Mantle: Berlin, Springer-Verlag, p. 53-80.

Stampfli, G.M., and Hochard, C., 2009, Plate tectonics of the Alpine realm, in Murphy, J.B., Keppie, J.D., and Hynes, A.J., eds., Ancient Orogens and Modern Analogues: Geological Society of London Special Publication 327, p. 89-111.

Stampfli, G.M., and Kozur, H.W., 2006, Europe from the Variscan to the Alpine cycles, in Gee, D.G., and Stephenson, R.A., eds., European Lithosphere Dynamics: Geological Society of London Memoir 32, p. 57-82.

Stampfli, G.M., Mosar, J., Marquer, D., Marchant, R., Baudin, T., and Borel, G., 1998, Subduction and obduction processes in the Swiss Alps: Tectonophysics, v. 296, p. 159-204, doi:10.1016/S0040-1951(98)00142-5.

Stampfli, G.M., Borel, G.D., Cavazza, W., Mosar, J., and Ziegler, P.A., 2001a, Palaeotectonic and palaeogeographic evolution of the western Tethys and PeriTethyan domain (IGCP Project 369): Episodes, v. 24, p. 222-227.

Stampfli, G.M., Mosar, J., Favre, P., Pillevuit, A., and Vannay, J.-C., 2001b, Permo-Mesozoic evolution of the western Tethyan realm: The Neotethys/ East-Mediterranean connection, in Peritethyan rift/wrench basins and passive margins, in Ziegler, P.A., Cavazza, W., Robertson, A.H.F., and Crasquin-Soleau, S., eds., Stratigraphy and Evolution of Peri-Tethyan Platforms: Mémoires du Muséum National d'Histoire Naturelle, PeriTethys Memoir 6, v. 186, p. 51-108.

Stampfli, G.M., Borel, G., Marchant, R., and Mosar, J., 2002, Western Alps geological constraints on western Tethyan reconstructions: Journal of the Virtual Explorer, v. 8, p. 77-106, doi:10.3809/jvirtex.2002.00057.

Stampfli, G.M., Vavassis, I., De Bono, A., Rosselet, F., Matti, B., and Bellini, M., 2003, Remnants of the Paleotethys oceanic suture-zone in the western Tethyan area: Bollettino della Società Geologica Italiana: Volume Speciale, v. 2, p. 1-23.

Steiner, C., Hobson, A., Favre, P., Stampfli, G.M., and Hernandez, J., 1998, Mesozoic sequence of Fuerteventura (Canary Islands): Witness of Early Jurassic sea-floor spreading in the central Atlantic: Geological Society of America Bulletin, v. 110, p. 1304-1317, doi:10.1130/0016-7606(1998) $110<1304: \mathrm{MSOFCI}>2.3 . \mathrm{CO} ; 2$.
Tari, V., 2002, Evolution of the northern and western Dinarides: A tectonostratigraphic approach, in Bertotti, G., Schulmann, K., and Cloetingh, S.A.P.L., eds., Continental Collision and the Tectono-Sedimentary Evolution of Forelands: Katlenburg-Lindau, Copernicus, Stephan Mueller Special Publication Series 1, 223-236.

Tchoumatchenco, P., 2006, Jurassic tectonics of Bulgaria and the adjacent areas: Review of the Bulgarian Geological Society, v. 67, p. 86-103.

Tchoumatchenco, P., and Sapunov, I., 1994, Intraplate tectonics in the Bulgarian part of the Moesian Platform during the Jurassic: Geologica Balcanica, v. 24, p. 3-12.

Tchoumatchenko, P., Peybernes, B., Cernjavska, S., Lachkar, G., Surmont, J., Dercourt, J., Ivanov, Z., Rolando, J.P., Sapunov, I., and Thierry, J., 1992 Etude d'un domaine de transition Balkan-Moésie; évolution paléogéographique et paléotectonique du sillon du flysch jurassique inferieur et moyen dans la Stara Planina orientale (Bulgarie orientale): Bulletin de la Société Géologique de France, v. 163, p. 49-61.

Tollmann, A., ed., 1985, Geologie von Österreich: Wien, Franz Deuticke.

Trümpy, R., ed., 1981, Geology of Switzerland: A Guide Book: Part A. An Outline Geology of Switzerland. Part B. Geological Excursions: Basel, Wepf $\& \mathrm{Co}, 334 \mathrm{p}$.

Vera, J.-A., 2001, Evolution of the South Iberian continental margin, in Ziegler, P.A., Cavazza, W., Robertson, A.H.F., and Crasquin- Soleau, S., eds., Stratigraphy and Evolution of Peri-Tethyan Platforms: Mémoires du Muséum National d'Histoire Naturelle, Peri-Tethys Memoir 6, v. 186, p. 109-143.

Vishnevskaya, V.S., Djeric, N., and Zakariadze, G.S., 2009, New data on Mesozoic Radiolaria of Serbia and Bosnia, and implications for the age and evolution of oceanic volcanic rocks in the Central and Northern Balkans: Lithos, v. 108, p. 72-105, doi:10.1016/j.lithos.2008.10.015.

Wildi, W., 1979, Evolution de la plate-forme carbonatée de type austro-alpin de la Dorsale calcaire (Rif interne, Maroc septentrional) au Mésozoïque: Bulletin de la Société Géologique de France, v. 21, p. 49-56.

Wildi, W., 1981, Le Ferrysch; cone de sedimentation detritique en eau profonde à la bordure nord-ouest de l'Afrique au Jurassique moyen à superieur (Rif externe, Maroc): Eclogae Geologicae Helvetiae, v. 74, p. 481-527.

Wildi, W., 1983, La chaîne tello-rifaine (Algerie, Maroc, Tunisie); structure stratigraphie et evolution du Trias au Miocene: Revue de Géologie Dynamique et de Géographie Physique, v. 24, p. 201-297.

Wilmsen, M., Fürsich, F.T., and Taheri, J., 2009, The Shemshak Group (LowerMiddle Jurassic) of the Binalud Mountains, NE Iran: Stratigraphy, depositional environments and geodynamic implications, in Brunet, M.-F., Wilmsen, M., and Granath, J.W., eds., South Caspian to Central Iran Basins: Geological Society of London Special Publication 312, p. 175188, doi:10.1144/SP312.8.

Zarcone, G., and Di Stefano, P., 2010, La Piattaforma carbonatica Panorimide; un caso anomalo nell'evoluzione dei bacini della Tetide giurassica: Italian Journal of Geosciences, v. 129, p. 188-194.

Ziegler, P.A., 1988, Evolution of the Arctic-North Atlantic and the Western Tethys: American Association of Petroleum Geologists Memoir 43, 198 p.

Manuscript Accepted by the Society 6 September 2013 